\title{
РАЗРАБОТКА СТЕНДА ДЛЯ ОПРЕДЕЛЕНИЯ ХАРАКТЕРИСТИК ШТОРНО-ЩЕЛЕВЫХ ЗАТВОРОВ
}

\section{Дмитрий Николаевич Раков}

Сибирский государственный университет геосистем и технологий, 630108, Россия, г. Новосибирск, ул. Плахотного, 10, ассистент кафедры геоматики и инфраструктуры недвижимости, ассистент кафедры кадастра и территориального планирования, тел. (913)769-74-50, e-mail: rd.bbla@gmail.com

\section{Вячеслав Николаевич Никитин}

Сибирский государственный университет геосистем и технологий, 630108, Россия, г. Новосибирск, ул. Плахотного, 10, кандидат технических наук, доцент кафедры фотограмметрии и дистанционного зондирования, тел. (913)712-37-50, e-mail: vslav.nikitin@gmail.com

\section{Светлана Александровна Ракова}

Сибирский государственный университет геосистем и технологий, 630108, Россия, г. Новосибирск, ул. Плахотного, 10, ассистент кафедры геоматики и инфраструктуры недвижимости, аспирант, тел. (953)789-83-53, e-mail: chernonozhkina_s.a@mail.ru

В статье приведено описание принципиально нового метода определения параметров шторно-щелевого затвора. Основой предлагаемого метода является специализированный измерительный стенд, состоящий из нескольких светодиодных лент. Ленты переключаются по принципу бегущей волны. Такой стенд позволяет добиться эффекта "волны" на изображении.

Ключевые слова: шторно-щелевой затвор, аэрофотосъемка, БПЛА, БЛА, аэрофотоаппарат, фотоаппарат, измерительный стенд, ортоскопия

\section{DEVELOPMENT OF A STAND FOR DETERMINING THE CHARACTERISTICS OF CURTAIN-SLIT VALVES}

\section{Dmitry N. Rakov}

Siberian State University of Geosystems and Technologies, 10, Plakhotnogo St., Novosibirsk, 630108, Russia, Assistant, Department of Geomatics and Real Estate Infrastructure, Assistant, Department of Cadastre and Territorial Planning, phone: (913)769-74-50, e-mail: rd.bbla@gmail.com

\section{Vyacheslav N. Nikitin}

Siberian State University of Geosystems and Technologies, 10, Plakhotnogo St., Novosibirsk, 630108, Russia, Ph. D., Associate Professor, Department of Photogrammetry and Remote Sensing, phone: (913)712-37-50, e-mail: vslav.nikitin@gmail.com

\section{Svetlana A. Rakova}

Siberian State University of Geosystems and Technologies, 10, Plakhotnogo St., Novosibirsk, 630108, Russia, Assistant, Department of Geomatics and Real Estate Infrastructure, Ph. D. Student, phone: (953)789-83-53, e-mail: chernonozhkina_s.a@mail.ru

The article describes a fundamentally new method for determining the parameters of a focalplane shutter. The proposed method is based on a specialized measuring stand consisting of several LED strips. The tapes are switched according to the traveling wave principle. Such a stand allows you to achieve a "wave" effect on the image. 
Keywords: focal plane shutter, aerial photography, UAV, UAV, aerial camera, camera, measuring stand, orthoscopy

В ходе выполнения аэрофотосъемочных работ возможно нарушение геометрии формируемых изображений из-за особенностей работы затворов фотоаппаратов. Особенно этому подвержены цифровые фотоаппараты, оснащенные шторно-щелевыми затворами. Такие нарушения возникают только при перемещении объекта фотографирования относительно камеры. В настоящее время практически все производители беспилотных летательных аппаратов в качестве полезной нагрузки используют цифровые не метрические фотоаппараты, оснащенные шторно-щелевыми затворами. Устройство такого затвора сравнительно простое.

Управление выдержкой осуществляется изменением скорости шторок и расстояния между ними. При работе шторно-щелевого затвора возникают геометрические искажения по причине того, что экспонирование щелью различных точек местности происходит в разные моменты времени. В зависимости от направления движения шторки, относительно направления полета, искажение может иметь различные виды. На рисунке схематично показаны искажения в изображении квадрата, зависящие от направления движения затвора v и направления полета W.

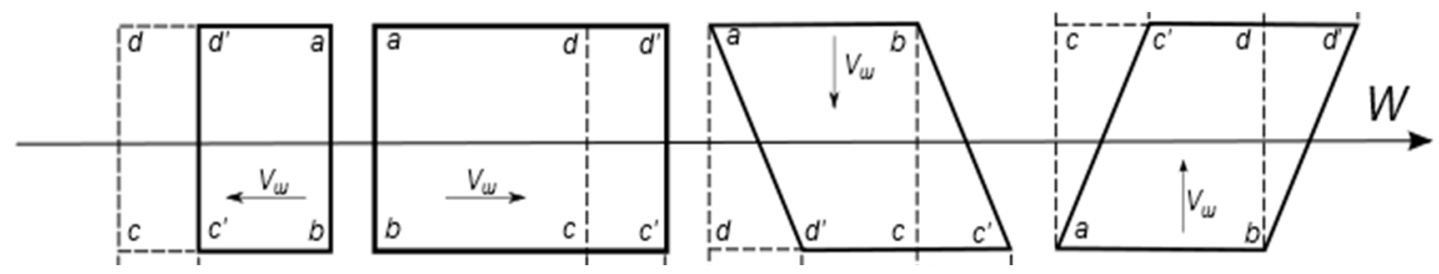

Искажения изображения в зависимости от взаимного направления движения шторок и летательного аппарата

Основой разработанного метода является измерительный стенд, состоящий из нескольких светодиодных лент, переключающихся по принципу бегущей волны. Основным параметром работы стенда является время между переключением светодиодных лент.

При фотографировании стенда необходимо обеспечить выполнение следующих условий:

1) оптическая ось объектива должна была перпендикулярна плоскости стенда;

2) светодиодные ленты должны располагаться вдоль вектора движения шторок и полностью перекрывать кадр от края до края.

Из-за того, что фактическая выдержка фотоаппарата значительно превышает эффективную выдержку, на снимке стенда будет изображена «волна» из горящих светодиодов.

Для определения режима работы шторно-щелевого затвора необходимо выполнить анализ фронта переключения светодиодов непосредственно по 
зафиксированному изображению. Для этого на снимке проводятся линии, отделяющие горящие и не горящие светодиоды. Угол наклона данной линии будет зависеть от времени переключения между светодиодными лентами, расстояния между ними и скоростью движения шторок.

Эффективная выдержка будет определяться задержкой между фазами работы открывающей и закрывающей шторок.

Фактическая выдержка будет вычисляться как сумма продолжительности фазы открытия шторки и эффективной выдержки.

В завершении хотелось бы отметить, что предложенный метод определения параметров шторно-щелевого затвора позволяет построить математически строгую модель формирования фотографического изображения и, следовательно, выполнять уравнивание материалов аэрофотосъемки, опираясь на результаты лабораторных исследований и сертификации цифровых камер.

Работоспособность данного метода подтверждена наличием функционирующего измерительного стенда и комплексом проведенных исследований по определению характеристик шторно-щелевого затвора камеры.

\section{БИБЛИОГРАФИЧЕСКИЙ СПИСОК}

1. Милчев М. М. Цифровые фотоаппараты. - СПб. : Питер, 2004. - 249 с.

2. Бабаев С. Н. Технология мониторинга открытых горных работ с применением беспилотного летательного аппарата // Интерэкспо ГЕО-Сибирь-2013. IX Междунар. науч. конгр. : Междунар. науч. конф. «Геодезия, геоинформатика, картография, маркшейдерия» : сб. материалов в 3 т. (Новосибирск, 15-26 апреля 2013 г.). - Новосибирск : СГГА, 2013. Т. 3. - С. 151154. Вестник СГУГиТ, Том 24, № 3, 201992.

3. Применение малых беспилотных летательных аппаратов для съемки местности и подготовки геоинформационного контента в чрезвычайных ситуациях / В. К. Барбасов, П. Р. Руднев, П. Ю. Орлов, А. В. Гречищев // Интерэкспо ГЕО-Сибирь-2013. IX Междунар. науч. конгр. : Междунар. науч. конф. «Геодезия, геоинформатика, картография, маркшейдерия» : сб. материалов в 3 т. (Новосибирск, 15-26 апреля 2013 г.). - Новосибирск : СГГА, 2013. Т. 2 - С. 158-163.

4. Шрайнер К. А., Макаров И. В. Использование возможностей беспилотных летательных аппаратов для дистанционного зондирования на примере открытых горных работ // Вестник СГГА. - 2012. - Вып. 2 (18). - С. 47-50.

5. Эпов М. И., Злыгостев И. Н. Применение беспилотных летательных аппаратов в аэрогеофизической разведке // Интерэкспо ГЕО-Сибирь-2012. VIII Междунар. науч. конгр. : Междунар. науч. конф. «Дистанционные методы зондирования Земли и фотограмметрия, мониторинг окружающей среды, геоэкология» : сб. материалов в 2 т. (Новосибирск, 10-20 апреля 2012 г.). - Новосибирск : СГГА, 2012. Т. 2. - С. 22-27.

6. Костюк А. С., Быков А. Л., Быков Л. В. Методика калибровки и предварительной обработки снимков, полученных трехкамерной фотографической системой с беспилотного летательного аппарата // Интерэкспо ГЕО-Сибирь-2012. VIII Междунар. науч. конгр. : Междунар. науч. конф. «Дистанционные методы зондирования Земли и фотограмметрия, мониторинг окружающей среды, геоэкология» : сб. материалов в 2 т. (Новосибирск, 10-20 апреля 2012 г.). - Новосибирск : СГГА, 2012. Т. 1. - С. 28-31.

7. Деришев Д. С., Деришев С. Г. Беспилотные авиационные комплексы для геофизических исследований и мониторинга земной поверхности // ГЕО-Сибирь-2010. VI Междунар. науч. конгр. : сб. материалов в 6 т. (Новосибирск, 19-29 апреля 2010 г.).-Новосибирск : СГГА, 2010. Т. 4, ч. 1. - C. 46-50. 
8. Костюк А. С. Расчет параметров и оценка качества аэрофотосъемки с БПЛА [Текст] // ГЕО-Сибирь-2010. VI Междунар. науч. конгр. : сб. материалов в 6 т. (Новосибирск, 19-29 апреля 2010 г.). - Новосибирск : СГГА, 2010. Т. 4, ч. 1. - С. 83-87.

9. Оценка точности 3D-моделей, построенных с использованием беспилотных авиационных систем / Е. И. Аврунев, Х. К. Ямбаев, О. А. Опритова, А. В. Чернов, Д. В. Гоголев // Вестник СГУГиТ. - 2018. - Т. 23, № 3. - С. 211-228.

10. Хлебникова Т. А., Опритова О. А. Экспериментальные исследования точности построения плотной цифровой модели по материалам беспилотной авиационной системы // Вестник СГУГиТ. - 2018. - Т. 22, № 2. - С. 119-129.

11. Никитин В. Н., Семенцов А. В. Опыт построения ортофотоплана по данным крупномасштабной аэрофотосъемки, выполненной с использованием неметрической цифровой камеры // Интерэкспо ГЕО-Сибирь-2013. IX Междунар. науч. конгр. : Междунар. науч. конф. «Дистанционные методы зондирования Земли и фотограмметрия, мониторинг окружающей среды, геоэкология» : сб. материалов в 2 т. (Новосибирск, 15-26 апреля 2013 г.). - Новосибирск : СГГА, 2013. Т. 1. - С. 12-18.

12. Михайлов А. П., Монтель Андраде Э. Р., Мануэль Де Хесус П. В. О применении цифровых фотокамер со шторно-щелевым затвором для выполнения аэрофотосъемки с легкомоторных и беспилотных летательных аппаратов // Изв. вузов. Геодезия и аэрофотосъемка. 2013. - № 4. - С. 30-32. $184 \mathrm{c}$.

13. Аржанов Е. П., Ильин В. Б. Аэрофотосъемочное оборудование. - М. : Недра, 1972. -

14. Лаврова Н. П., Стеценко А. Ф. Аэрофотосъемка. Аэрофотосъемочное оборудование : учебник для вузов. - М. : Недра, 1981. - 296 с.

15. Кучко А. С. Аэрофотография (Основы и метрология). - М. : Недра, 1974. - 272 с.

16. Антипов И. Т. Развитие фотограмметрии в России // ГЕО-Сибирь-2010. VI Междунар. научн. конгр. : Пленарное заседание : сб. материалов (Новосибирск, 19-29 апреля 2010 г.). - Новосибирск : СГГА, 2010. - С. 97-132.

17. Раков Д. Н., Никитин В. Н., Шевчук С. О. Определение задержки срабатывания затворов фотоаппаратов в аэрофотосъемочных комплексах // Интерэкспо ГЕО-Сибирь-2014. Х Междунар. науч. конгр. : Междунар. науч. конф. «Дистанционные методы зондирования Земли и фотограмметрия, мониторинг окружающей среды, геоэкология» : сб. материалов в 2 т. (Новосибирск, 8-18 апреля 2014 г.). - Новосибирск : СГГА, 2014. Т. 1. - С. 61-66.

(С) Д. Н. Раков, В. Н. Никитин, С. А. Ракова, 2021 